

\title{
Implementasi Model Pembelajaran Kooperatif Tipe TGT Berbantuan Papan Game Number One untuk Meningkatkan Hasil Belajar Siswa
}

\author{
Lalu Usman Ali ${ }^{1 *}$, Tirmayasari $^{2}$, Muhammad Zaini ${ }^{3}$ \\ ${ }^{1,3)}$ Program Studi Tadris Fisika, Fakultas Tarbiyah dan Keguruan, Universitas Islam Negeri Mataram, Jl. \\ Pendidikan No. 35 Mataram, Indonesia \\ ${ }^{2}$ SMP N 5 Praya Timur, Kab. Lombok Tengah, Indonesia
}

*E-mail korespondensi: usmanalilalu@uinmataram.ac.id

\begin{abstract}
Info Artikel: Abstrak
Dikirim:

12 April 2021

Revisi:

1 Juni 2021

Diterima:

23 Juni 2021

\section{Kata Kunci:}

TGT, Hasil

Belajar, Respon,

Siswa, Papan

Game Number

One

Penelitian ini bertujuan untuk meningkatkan hasil belajar, dan mendeskripsikan respons siswa terhadap penerapan model pembelajaran kooperatif tipe TGT Berbantuan Papan Game Number One pada pembelajaran Ilmu Pengetahuan Alam (IPA). Subjek penelitian ini adalah siswa kelas VII SMP N 5 Praya Timur pada semester ganjil tahun pelajaran 2019/2020 yang berjumlah 23 orang. Objek penelitian ini adalah hasil belajar dan respons siswa. Penelitian ini dilakukan dalam dua siklus pembelajaran dengan tahapan-tahapan dalam setiap siklus meliputi perencanaan, tindakan, observasi/evaluasi, dan refleksi. Data hasil belajar siswa dikumpulkan melalui pengisian lembar kerja siswa (LKS)/tugas, nilai game/permainan, dan tes akhir siklus. Data respons siswa dikumpulkan dengan kuesioner. Data yang telah terkumpul selanjutnya dianalisis secara deskriptif. Penelitian dikatakan berhasil apabila aspek hasil belajar menunjukkan Daya Serap Siswa (DSS) $\geq$ Keriteria Ketuntasan Minimal (KKM) yaitu 70 dan Ketuntasan Klasikal (KK) $\geq 85 \%$, dan respons siswa minimal berkategori positif. Hasil penelitian menunjukkan terjadi peningkatan nilai rata-rata hasil belajar siswa yaitu dari 74,0 dengan ketuntasan klasikal 73,9\% dan standar deviasi 6,8 pada siklus I menjadi 75,5 dengan ketuntasan klasikal 87\% dan standar deviasi 6,4 pada siklus II, dan respons siswa terhadap penerapan model pembelajaran kooperatif tipe TGT Berbantuan Papan Game Number One diperoleh skor rata-rata sebesar 77,8 dengan standar deviasi 2,3 dan kategori positif. Hasil analisis data tersebut menunjukkan penerapan model pembelajaran kooperatif tipe TGT Berbantuan Papan Game Number One dapat meningkatkan hasil belajar siswa kelas VII SMP N 5 Praya Timur pada Tahun Pelajaran 2019/2020.
\end{abstract}

(C) 2021 Universitas Islam Negeri Mataram

\section{PENDAHULUAN}

Penerapan standar proses pendidikan merupakan kebijakan yang sangat penting dan strategis untuk pemerataan dan peningkatan kualitas pendidikan. Secara umum, peningkatan kualitas pendidikan telah direncanakan dan dilaksanakan saat ini, terbukti dari adanya penyempurnaan dan pelaksanaan Kurikulum Tingkat Satuan Pendidikan (KTSP). Melalui standar proses pendidikan, setiap guru dan pengelola sekolah dapat menentukan bagaimana seharusnya proses pembelajaran berlangsung. Kurikulum dan perangkat pembelajaran yang lain seperti silabus dan rencana pelaksanaan pembelajaran (RPP) telah mengacu pada standar proses yang ditetapkan. Hanya saja 
yang menjadi permasalahan adalah dalam pelaksanaan masih belum optimal, hal ini dapat dilihat dari masih rendahnya hasil belajar siswa.

Pada masa pandemi covid-19 SMPN 5 Praya Timur tetap masuk seperti biasa karena pertimbangan sarana dan prasarana pendukung sekolah dan siswa dalam proses pembelajaran. Hal ini, dimaksudkan oleh guru dan kepala sekolah untuk bisa memberikan pelayanan maksimal kepada siswa-siswi yang notabenenya berada di desa perbatasan Kabupaten Lombok Tengah dan Lombok Timur. Proses kegiatan belajar dan mengajar (KBM) pada masa pandemi ini tetap memperhatikan protokol kesehatan. KBM dilaksanakan secara tatap muka dengan pertimbangan jumah siswa masing-masing kelas sedikit.

Pada proses KBM, SMP N 5 Praya Timur juga mengalami permasalahan, yaitu rendahnya hasil belajar dan motivasi belajar siswa khususnya pembelajaran Ilmu Pengetahuan Alam (IPA) di kelas. Hal ini terlihat dari pantauan guru dalam proses pembelajaran dan hasil tes, ulangan harian yang dilaksanakan oleh guru di kelas VII SMP N 5 Praya Timur. Rendahnya hasil belajar siswa merupakan salah satu indikator yang erat kaitannya dengan peranan guru sebagai pengajar di dalam kelas. Dimana, untuk mencapai tujuan pembelajaran secara optimal diperlukan perencanaan yang sistematis dari guru yang memuat bagaimana mengelola proses pembelajaran agar bermakna bagi siswa.

Berdasarkan pengamatan dan analisa guru bahwa ada beberapa faktor yang menjadi penyebab rendahnya kualitas pendidikan dalam kegiatan belajar mengajar (KBM), antara lain yaitu: (1) Kurang pemanfaatan media pembelajaran, pembelajaran yang dilaksanakan dalam PBM di kelas berpanduan hanya dari ceramah guru, karena sebagian siswa tidak memiliki buku pegangan; (2) Waktu pembelajaran IPA yang kurang sesuai, jadwal mata pelajaran IPA di kelas VII setiap pertemuan pada jam terakhir (jam ke 7 dan 8) sehingga membuat para siswa kurang konsentrasi dalam PBM; (3) Guru kurang merefleksi keadaan nyata yang terjadi di dalam kelas; dan (4) Pemilihan metode pembelajaran yang kurang atau tidak sesuai dengan karakteristik mata pelajaran IPA dan karakter siswa itu sendiri; (5) Motivasi belajar siswa masih relatif rendah ini ada kaitannya dengan faktor izin dari orang tua, ada sebagian orang tua selama covid tidak mengizinkan anaknya masuk sekolah sehingga ketinggalan materi pelajaran. Hal ini disebabkan juga oleh KBM selama masa pandemi yang membuat rasa khawatir tinggi. Oleh karena itu, penulis bermaksud memberikan pembelajaran yang inovatif guna meningkatkan motivasi belajar siswa. (6) Aktivitas dalam mengikuti kegiatan belajar mengajar masih relatif rendah. Hal ini dilihat dari tingkah laku siswa yang masih banyak menunjukkan perilaku kurang disiplin seperti siswa bercanda ketika di kelas, interaksi antar siswa dengan guru dan siswa antar siswa kurang efektif. (7) Hasil belajar siswa relatif rendah, hal ini disebabkan karena kurang maksimal pemanfaatan media dan pembelajaran inovatif ketika mengelola pembelajaran siswa. Selain itu kondisi pandemi covid-19 yang terjadi atau melanda dunia menjadikan pembelajaran berjalan kurang efektif.

Berdasarkan uraian di atas dapat dikatakan bahwa guru memiliki peranan yang sangat strategis pada proses pembelajaran. Seorang guru harus siap berperan sebagai fasilitator dan mediator, yang membimbing dan memilih model pembelajaran yang konstruktif, inovatif, variatif, menyenangkan dan bermakna, sehingga dapat mengaktifkan aktivitas belajar pada diri siswa [1]. Dalam proses belajar mengajar, siswa dan guru memainkan peran yang terdefinisi dengan baik, dimana siswa diberi peran utama sebagai tokoh utama dan guru berperan sebagai organisator, pembimbing dan fasilitator. Pengetahuan bukan sesuatu yang diserap secara pasif oleh seseorang siswa/peserta didik melainkan sesuatu yang diciptakan sendiri secara aktif oleh siswa [2]-[4].

Berdasarkan permasalahan-permasalahan diatas, maka permasalahan inti yang akan dicari penyelesaiannya adalah motivasi belajar siswa yang relatif rendah, dan hasil belajar siswa yang belum mencapai ketuntasan klasikal maupun ketuntasan individual. Oleh karena itu, perlu ada penyempurnaan dalam proses pembelajaran melalui suatu pembelajaran yang aktif, inovatif, kreatif, efektif dan menyenangkan (PAIKEM) sehingga akan bermuara pada peningkatan motivasi belajar dan hasil belajar siswa [5]. Salah satu model pembelajaran yang dapat mengakomodasi peningkatan motivasi belajar dan hasil belajar siswa adalah pembelajaran kooperatif (Cooperative Learning). Pembelajaran kooperatif merupakan model pembelajaran yang dirancang untuk membelajarkan kecakapan akademik (academic skiil), sekaligus keterampilan social (social skiil) termasuk 
interpersonal skill [6]. Pembelajaran ini diharapkan mampu menciptakan suasana kondusif untuk memberikan pengalaman belajar kepada peserta didik melalui pelibatan secara interaktif, inspiratif, menyenangkan, menantang, memotivasi peserta didik untuk berpartisipasi aktif, serta memberikan ruang bagi prakarsa, kreatifitas, dan kemandirian [7]. Salah satu pendekatan model pembelajaran kooperatif adalah model kooperatif tipe Team Games Tournament (TGT). Keunggulan model ini terletak pada modifikasi pada evaluasi yang dilakukan dengan menggunakan turnamen sehingga dengan metode turnamen tersebut mampu memberikan peningkatan motivasi belajar kepada siswa.

Model pembelajaran kooperatif tipe Team Games Tournament (TGT) memiliki langkahlangkah/sintaks pembelajaran, yaitu: (1) penyajian kelas, (2) belajar dalam kelompok, (3) permainan, (4) pertandingan, dan (5) penghargaan kelompok [8]. Kegiatan belajar mengajar pada model pembelajaran kooperatif tipe Team Games Tournament (TGT) lebih bervariasi karena dengan diskusi peserta didik dapat memupuk kerjasama antar anggota kelompoknya, dapat saling membantu sesama teman, saling menghargai pendapat orang lain, memotivasi peserta didik untuk berprestasi dalam memeroleh nilai terbaik antar kelompok dan dapat memotivasi peserta didik untuk lebih aktif dalam diskusi. Keunggulan pada model pembelajaran ini adalah terletak pada modifikasi pada evaluasi yang dilakukan dengan menggunakan turnament sehingga dengan metode turnamen tersebut mampu memberikan peningkatan motivasi belajar siswa yang berimplikasi langsung juga ke hasil belajar siswa [6].



Gambar 1. Papan Game Number One

Game atau permainan dapat meningkatkan motivasi anak-anak dalam setiap kegiatannya, begitulah pula siswa-siswa yang notabenenya adalah siswa kelas VII SMP/MTs. Periode umur siswa kelas VII SMP/MTs merupakan periode umur yang masih tergolong anak-anak yang relatif jiwa bermainnya sangat besar [9]. Permainan yang digunakan dalam pembelajaran ini dibantu oleh media berupa papan game number one. Media ini terbuat dari bahan sederhana seperti papan kayu licin dan cat (lihat gambar 1). Berdasarkan uraian di atas, maka untuk memberikan solusi pada pembelajaran siswa diterapkan Model Pembelajaran Kooperatif Tipe Team Group Tounament (TGT) Berbantuan Papan Game Number One untuk Meningkatkan Hasil Belajar Siswa Kelas VII SMP N 5 Praya Timur dan respons siswa kelas VII SMP N 5 Praya Timur tahun pelajaran 2019/2020 terhadap penerapan Model Pembelajaran Kooperatif Tipe Team Games Tournament (TGT) Berbantuan Papan Game Number One.

\section{METODE PENELITIAN}


Metode penelitian berisi tentang rancangan kegiatan penelitian, ruang lingkup atau objek, bahan dan alat utama, lokasi, teknik pengambilan data, teknik analisis data, definisi operasional variabel penelitian. Penelitian ini adalah penelitian tindakan kelas (PTK) yang dimana prosedur penelitiannya yaitu: (1) perencanaan; (2) tindakan; (3) observasi/evaluasi; dan (4) refleksi [10]. Responden pada penelitian ini adalah siswa kelas VII SMP N 5 Praya Timur tahun pelajaran 2019/2020.

Data aspek hasil belajar siswa dianalisis secara deskriptif, Skor hasil belajar siswa dibagi menjadi dua yaitu skor formatif dan skor sumatif. Skor formatif adalah skor yang diperoleh siswa setiap pertemuan, sedangkan skor sumatif adalah skor yang diperoleh siswa berdasarkan hasil tes hasil belajar setiap akhir siklus [11]. Untuk menentukan nilai hasil belajar siswa dianalisis berdasarkan nilai rerata formatif dan sumatif hasil belajar siswa. Skor hasil belajar siswa di konversi ke dalam skala 100. Skor akhir nilai hasil belajar siswa diketahui dengan perumusan nilai skor sumatif ditambah dengan nilai formatif siswa.

$$
\bar{X}_{\text {formatif }}=\frac{X_{1}+X_{2}+X_{3}+X_{4}}{4}
$$

\section{(Persamaan 1)}

Keterangan:

$\bar{X}_{\text {formatif }}=$ Rerata nilai formatif hasil belajar siswa

$\mathrm{X}_{1}, \mathrm{X}_{2}, \mathrm{X}_{3}, \mathrm{X}_{4} \quad=$ nilai hasil belajar siswa pertemuan 1, 2, 3, 4

$$
\bar{X}_{\text {sumatif }}=\frac{\sum X}{N}
$$

Keterangan:

$\begin{array}{ll}\bar{X}_{\text {sumatif }} & =\text { Rerata nilai sumatif hasil belajar siswa } \\ \sum_{\mathrm{N}} & =\text { Jumlah nilai tes hasil belajar siswa } \\ & =\text { Jumlah siswa }\end{array}$

Skor akhir nilai hasil belajar siswa diketahui dengan perumusan nilai skor sumatif ditambah dengan nilai formatif siswa, adapun secara matematis dapat dijelaskan sebagai berikut.

$$
\bar{X}_{\text {akhir }}=\frac{\bar{X}_{\text {formatf }}+\bar{X}_{\text {sumatif }}}{2}
$$

Keterangan:

(Persamaan 3)

$\bar{X}_{\text {akhir }} \quad=$ Nilai akhir nilai hasil belajar siswa

$\bar{X}_{\text {formatf }}=$ Rerata nilai formatif hasil belajar siswa

$\bar{X}_{\text {sumatif }}=$ Rerata nilaisumatif hasil belajar siswa

Ketuntasan hasil belajar siswa dapat ditentukan dengan menggunakan kriteria ketuntasan minimal (KKM), daya serap siswa (DSS) dan ketuntasan klasikal (KK) sebagai berikut.

1. Kriteria ketuntasan minimal (KKM)

Kriteria ketuntasan minimal di SMPN 5 Praya Timur untuk mata pelajaran IPA adalah 70. Kriteria keberhasilan tindakan yaitu jika nilai siswa $\geq 70$.

2. Daya serap siswa (DSS) dihitung dengan rumus sebagai berikut. 


$$
D S S=\frac{\text { Jumlah total skor yang dicapai siswa }}{\text { Jumlah total skor maksimum }} \times 100 \%
$$

Kriteria keberhasilan tindakan yaitu jika DSS $\geq 70 \%$. Daya serap siswa (DDS) di SMPN 5 Praya Timur identik dengan kriteria ketuntasan minimal (KKM) untuk mata pelajaran IPA. Jadi, kriteria keberhasilan tindakan jika DSS $\geq 70 \%$ atau nilai siswa $\geq 70$.

3. Ketuntasan klasikal (KK) dihitung dengan rumus sebagai berikut.

$$
K K=\frac{\text { Banyaknya siswa yang tuntas }}{\text { Banyaknya siswa yang ikut tes }} \times 100 \%
$$

Adapun indikator keberhasilan dari penelitian ini yaitu kriteria keberhasilan tindakan yaitu jika $\mathrm{KK} \geq 85 \%$, dan siswa dikatakan tuntas jika nilai siswa $\geq 70$ atau DSS $\geq 70 \%$ dan satu kelas dikatakan tuntas jika $\mathrm{KK} \geq 85 \%$.

Respons atau tanggapan siswa terhadap penerapan model pembelajaran kooperatif tipe Team Group Tournament (TGT) Berbantuan Papan Game Number One dikumpulkan dengan menggunakan kuesioner dan dihitung skor reratanya $(\bar{X})$. Model TGT dikatakan berhasil dan efektif jika memiliki respons minimal positif [12].

Tabel 1. Pedoman Penggolongan Respons Siswa

\begin{tabular}{|c|c|c|}
\hline No & Kriteria & Kategori \\
\hline 1 & $80,1 \leq \bar{X}$ & Sangat positif \\
\hline 2 & $66,7 \leq \bar{X}<80,1$ & Positif \\
\hline 3 & $53,3 \leq \bar{X}<66,7$ & Cukup positif \\
\hline 4 & $39,9 \leq \bar{X}<53,3$ & Kurang positif \\
\hline 5 & $\bar{X}<39,9$ & Sangat kurang positif \\
\hline
\end{tabular}

\section{HASIL DAN PEMBAHASAN}

Materi pelajaran yang dipelajari siswa dikelola dalam dua siklus pembelajaran, siklus I dilaksanakan menjadi tiga kali pertemuan dan siklus II di rinci menjadi tiga kali pertemuan. Tiap pertemuan dilaksanakan dua kali dalam seminggu dengan alokasi jam pelajaran (2 x 30 menit) sesuai dengan alokasi waktu selama pandemi. Penelitian ini dilaksanakan pada bulan Juli sampai September 2019. Perbandingan hasil penelitian antara siklus I dan siklus II dapat dilihat pada hasil belajar siswa. Data hasil penelitian dapat dilihat pada Tabel 2.

Tabel 2. Perbandingan Hasil Tindakan Siklus I dan II

\begin{tabular}{|c|c|l|l|}
\hline \multirow{2}{*}{ Aspek } & \multirow{2}{*}{ Keterangan } & \multicolumn{2}{|c|}{ Siklus } \\
\cline { 2 - 4 } & & \multicolumn{1}{|c|}{ I } & \multicolumn{1}{|c|}{ II } \\
\hline \multirow{4}{*}{ Hasil belajar } & Jumlah & 1702.0 & 1737.5 \\
\cline { 2 - 4 } & Rerata & 74.0 & 75.5 \\
\cline { 2 - 4 } & Standar deviasi & 6.8 & 6.4 \\
\cline { 2 - 4 } & Ketuntasan klasikal & 73.9 & 87.0 \\
\cline { 2 - 4 } & Kategori & Belum Tuntas & Tuntas \\
\hline Respons Siswa & \multicolumn{3}{|c}{ Positif } \\
\hline
\end{tabular}


Hasil belajar siswa adalah nilai yang diambil dari proses pembelajaran dengan menggunakan indikator tugas/PR, kuis, dan tes akhir siklus II. Nilai hasil belajar tersebut merupakan rerata dari nilai. Nilai hasil belajar siswa setiap pertemuan dirangkum dan ditunjukkan pada Tabel 2.

Berdasaran hasil analisis data hasil belajar siswa setelah dilaksanakan tindakan maka pada siklus I diperoleh nilai rata-rata hasil belajar siswa sebesar 74,0 dan ketuntas klasikalnya sebesar $73.9 \%$ dan standar deviasi 6,8 dengan kategori tidak tuntas. Hasil yang telah diperoleh siswa pada penelitian untuk siklus I dikatakan belum berhasil karena ketuntasan klasikal masih di bawah standar yang telah ditetapkan yaitu di bawah $85 \%$. Berdasarkan hasil observasi peneliti selama tindakan pada siklus I terungkap beberapa kendala atau hambatan yang perlu dicermati dalam mengimplementasikan model pembelajaran kooperatif tipe TGT pada mata pelajaran IPA. Permasalahan yang muncul yaitu (1) proses pembelajaran pada siklus I masih belum dapat berjalan secara optimal, (2) Siswa mengalami kesulitan dalam mengajukan hipotesis dari permasalahan yang diberikan, (3) Pelaksanaan tahapan TGT yang ke 2 dan ke 3 yaitu kerja dalam kelompok dan permainan belum optimal karena karena siswa harus jaga jarak dengan memakai protokol kesehatan sehingga siswa terbatas dan tidak menikmati permainannya dan kelihatan kaku, (4) Pada kegiatan presentasi atau diskusi kelompok, kinerja ilmiah siswa masih rendah. Sebagian besar siswa hanya menerima begitu saja pendapat atau hasil diskusi kelompok lain walaupun mereka memiliki pendapat yang berbeda. Sedangkan pada siklus II diperoleh nilai rata-rata hasil belajar siswa sebesar 75.5 dengan ketuntasan klasikal sebesar 87.0\% dan standar deviasi sebesar 6,4 dengan kategori tuntas. Hasil yang telah diperoleh siswa pada penelitian untuk siklus II dikatakan berhasil karena ketuntasan klasikal sudah melampui standar yang telah ditetapkan. Distribusi perbandingan nilai rata-rata hasil belajar siswa dalam grafik seperti ditunjukkan pada Gambar 2.

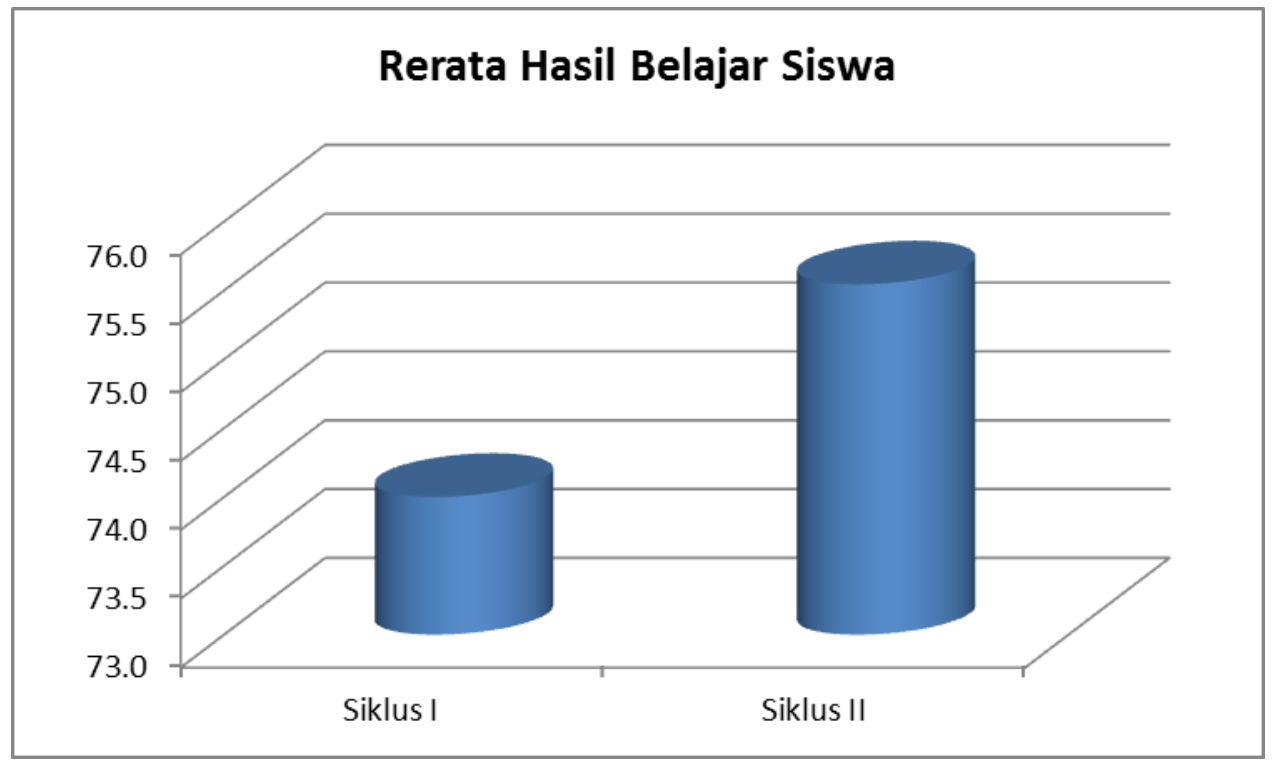

Gambar 2. Grafik Peningkatan Nilai Rata-Rata Hasil Belajar Siklus I dan Siklus II

Berdasarkan hasil analisis data tersebut, dapat disimpulkan bahwa penerapan model pembelajaran kooperatif tipe Team Group Tournament (TGT) Berbantuan Papan Game Number One dapat meningkatkan hasil belajar siswa. Hal ini dapat dilihat seperti gambar 2 di atas bahwa hasil belajar siswa mengalami peningkatan dari hasil belajar pada siklus I dan hasil belajar siklus II. Adapun persentase peningkatan hasil belajar dari siklus I ke siklus II sebesar 14 persen. Hal ini sejalan dengan hasil penelitian S.W.Bagja (2018) dan Oktarina (2019) yang menjelaskan bahwa penerapan model pembelajaran Team Games Tournament (TGT) dapat meningkatkan hasil belajar, keaktipan serta motivasi bagi peserta didik. Siswa memiliki peluang yang besar untuk dapat berinteraksi dengan siswa lain, saling mengisi kekurangan, dan melakukan tukar informasi yang lebih efektif, sehingga nantinya bermuara pada minimnya kesenjangan antara siswa yang berkemampaun tinggi dengan siswa yang berkemampuan rendah. Melalui kerja sama dalam kelompok, dan 
melakukan permainan untuk memahami suatu konsep dalam memecahkan masalah dalam kelompok yang heterogen, akan memberikan peluang besar kepada siswa untuk dapat mencapai hasil belajar yang optimal [13], [14].

Respons siswa terhadap penerapan model pembelajaran kooperatif tipe Team Group Tournament (TGT) Berbantuan Papan Game Number One pada penelitian ini dikumpulkan berdasarkan angket respons dalam bentuk kuesioner yang diberikan pada akhir siklus II. Berdasarkan hasil analisis skor respons siswa, diperoleh rerata respons siswa 38,9 atau dalam ratusannya adalah 77,8 dengan standar deviasi 2,3. Sebaran nilai respons siswa pada masing-masing kategori yang telah ditetapkan ditunjukkan pada Tabel 3.

Tabel 3. Sebaran Nilai Respon Siswa Terhadap Model TGT

\begin{tabular}{|c|c|c|c|c|}
\hline No & Kriteria & Frekuensi & Persentase & Kategori \\
\hline 1 & $80,1 \leq \bar{X}$ & 5 & 21,7 & Sangat positif \\
\hline 2 & $66,7 \leq \bar{X}<80,1$ & 18 & 78,3 & Positif \\
\hline 3 & $53,3 \leq \bar{X}<66,7$ & 0 & 0 & Cukup positif \\
\hline 4 & $39,9 \leq \bar{X}<53,3$ & 0 & 0 & Kurang positif \\
\hline 5 & $\bar{X}<39,9$ & 0 & 0 & $\begin{array}{c}\text { Sangat kurang } \\
\text { positif }\end{array}$ \\
\hline
\end{tabular}

Keterangan: jumlah siswa kelas VII $=23$ orang

Berdasarkan Tabel 3 penggolongan respons siswa pada kategori positif. Hal ini menunjukkan bahwa penerapan model pembelajaran kooperatif tipe Team Group Tournament (TGT) Berbantuan Papan Game Number One dikatakan berhasil. Distribusi respons siswa terhadap penerapan model pembelajaran kooperatif tipe Team Group Tournament (TGT) Berbantuan Papan Game Number One disajikan dalam diagram seperti ditunjukkan pada Gambar 3.

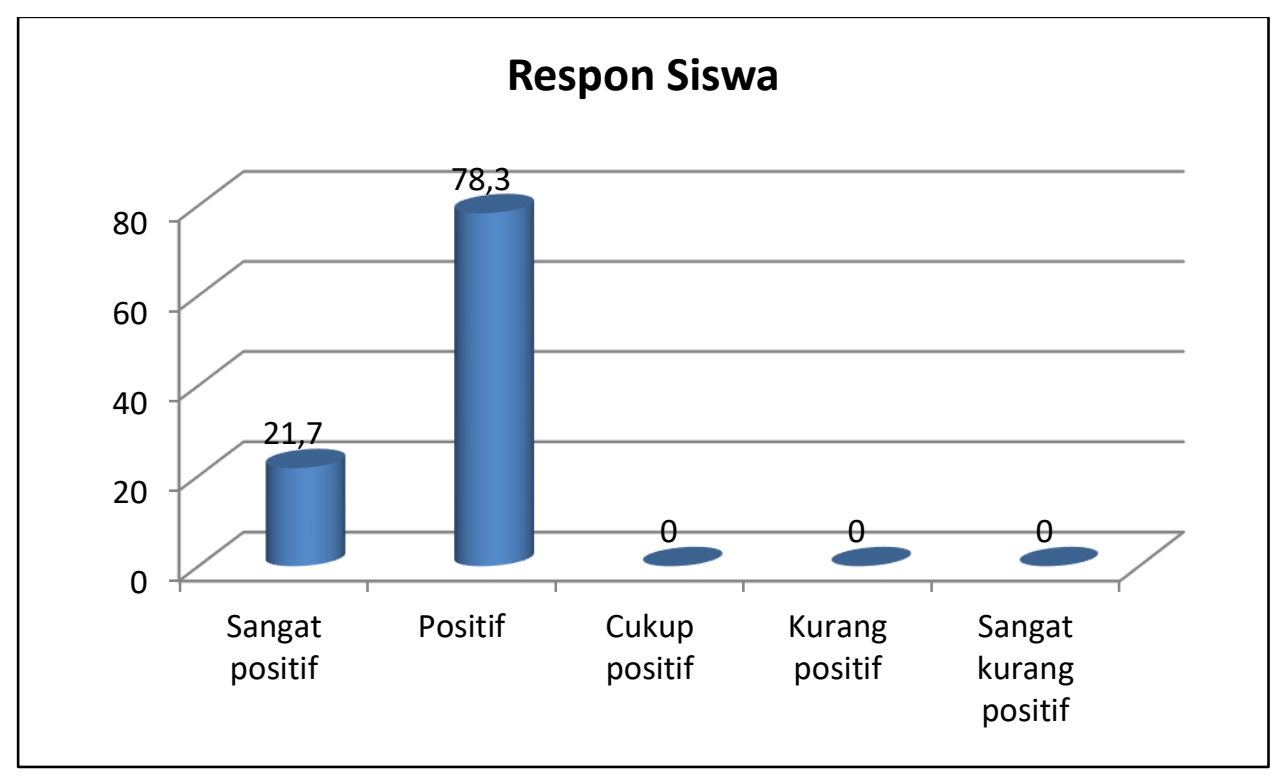

Gambar 3. Grafik Respons Siswa

Berdasarkan hasil analisis data diperoleh respons siswa sangat positif sebesar $21,7 \%$, positif sebesar 78,3\%, cukup positif sebesar $0 \%$, kurang positif sebesar $0 \%$, dan sangat kurang positif sebesar 0\%. Secara umum rerata nilai respon siswa kelas VII SMP N 5 Praya Timur terhadap penerapan model pembelajaran kooperatif tipe Team Group Tournament (TGT) Berbantuan Papan Game Number One yaitu 77,8 berada pada kategori positif. Siswa memberikan kesan bahwa dengan model pembelajaran ini memberikan kesempatan kepada mereka untuk dapat memperoleh hasil belajar yang optimal serta dapat menumbukan motivasi belajar. Hal ini sejalan dengan hasil 
penelitian yang menemukan bahwa respon siswa terhadap model pembelajaran kooperatif tipe TGT sebesar 69,2\% dengan kategori sangat positif, hal ini menunjukkan bahwa siswa menyukai pembelajaran yang telah diterapkan [15] [16].

Berdasarkan analisis data siklus I dan siklus II, tampak terlihat terjadi peningkatan nilai ratarata hasil belajar siswa dan diperoleh ketuntasan klasikal pada siklus I sebesar 73,9\% dan ketuntasan klasikal siklus II 87,0\% sehingga peningkatan 13,0\%. Hal ini menunjukkan bahwa penerapan model pembelajaran kooperatif tipe Team Group Tournament (TGT) Berbantuan Papan Game Number One dapat meningkatkan hasil belajar siswa dalam pembelajaran Ilmu Pengatahuan Alam (IPA) di SMP N 5 Praya Timur dengan respon siswa positif.

\section{KESIMPULAN}

Berdasarkan hasil belajar siswa yang diperoleh pada siklus I dan siklus II tersebut, maka pelaksanaan tindakan yang dilakukan dapat dikatakan mampu meningkatkan hasil belajar siswa SMPN N 5 Praya Timur tahun pelajaran 2019/2020. Hal ini dapat terjadi karena penerapan model pembelajaran kooperatif tipe Team Group Tournament (TGT) Berbantuan Papan Game Number One memberikan peluang yang luas kepada siswa untuk beraktivitas dan mengembangkan pola pikirnya dalam pembelajaran di kelas. Lebih lanjut berdasarkan hasil refleksi yang dilakukan, model pembelajaran kooperatif tipe Team Group Tournament (TGT) Berbantuan Papan Game Number One memiliki beberapa kebaikan yang dapat digunakan sebagai rekomendasi bagi guru dalam penerapan model tersebut di kelas. Adapun kebaikan-kebaikan tersebut seperti (1) Meningkatkan motivasi belajar siswa, (2) Meningkatkan kemampuan pemecahan masalah, (3) Meningkatkan kecakapan kolaborasi, (4) Meningkatkan keterampilan mengelola sumber yaitu bertanggung jawab untuk menyelesaikan tugas yang kompleks, dan (5) Meningkatkan mental juara dan bersaing siswa.

\section{UCAPAN TERIMA KASIH}

Penyelesaian penelitian ini tidak terlepas dari bantuan berbagai pihak, Oleh karena itu pada kesempatan ini penulis sampaikan terima kasih atas segala dukungan, kritik dan saran yang diberikan terutama kepada Drs. Abdul Hanan H selaku Kepala SMPN 5 Praya Timur dan Tim Guru yang menerapkan inovasi model pembelajaran di kelasnya walau dalam kondisi pandemi covid-19.

\section{DAFTAR PUSTAKA}

[1] I. W. Santyasa, "Model-model pembelajaran inovatif," Univ. Pendidik. Ganesha, 2007.

[2] T. Asmiyanto, "Menggagas Pembelajaran Aktif," Tersedia Pada Httpwmw Cedsid Org, 2008.

[3] I. Suastra, Pembelajaran Sains Terkini: Mendekatkan Siswa dengan Lingkungan Alamiah dan Sosial Budayanya. Singaraja: Penerbit Universitas Pendidikan Ganesha, 2009.

[4] Suparno, Filsafat Konstruktivisme dalam Pendidikan. Yogyakarta: Kanisius, 1999.

[5] S. Agus, "Cooperative learning teori dan aplikasi paikem," Yogyak. Pustaka Pelajar, 2009.

[6] L. U. Ali, Inovasi Pembelajaran: Solusi Pembelajaran bagi Pendidik. Mataram: CV Sanabil, 2020.

[7] D. P. Nasional, "Peraturan menteri pendidikan nasional nomor 41 tahun 2007 tentang standar proses untuk satuan pendidikan dasar dan menengah," Jk.t. Badan Standar Nas. Pendidik., 2007.

[8] R. E. Slavin, Cooperative Learning. Jakarta: Proyek Pendidikan Guru Sekolah Dasar Direktorat Jenderal Pendidikan Tinggi Departemen Pendidikan Dan Kebudayaan, 1995.

[9] M. Zaini, N. P. Adi, and L. U. Ali, "Physics Comprehensive Contextual Teaching Material Untuk Meningkatkan Kemampuan Argumentasi," KONSTAN-J. Fis. DAN Pendidik. Fis., vol. 5, no. 2, pp. 52-60, 2020.

[10] S. Kemmis, B. Atweh, and P. Weeks, Action Research In Practice: Partnership For Social Jusice In Education. London: Routledge, 2005.

[11] S. Arikunto, Penelitian tindakan kelas: Edisi revisi. Bumi Aksara, 2021.

[12] W. Nurkancana and P. Sunartana, "Evaluasi kinerja ilmiah," 1992.

[13] W. B. Sulfemi, "Penggunaan Teams Games Tournament (Tgt) Dengan Media Kartu Dalam Meningkatkan Hasil Belajar,” J. Komodo Sci. Educ., vol. 1, no. 01, pp. 1-14, 2018. 
[14] D. Oktarika and N. F. M. Putri, "Upaya Meningkatkan Hasil Belajar Siswa Menggunakan Model Pembelajaran Kooperatif Tipe Teams Games Tournaments (TGT) Berbantuan Media Prezi Dalam Materi Perakitan Komputer," Efektor, vol. 6, no. 2, pp. 115-119, 2019.

[15] W. Wiwit, A. Hermansyah, and P. Dody Dori, "Penerapan Model Pembelajaran Kooperatif Tipe TGT Dengan Dan Tanpa Penggunaan Media Animasi Terhadap Hasil Belajar Kimia Siswa SMA Negeri 9 Kota Bengkulu," Exacta, vol. 10, no. 1, pp. 71-78, 2012.

[16] D. Seftina, "Meningkatkan hasil belajar siswa pada konsep reaksi reduksi oksidasi melalui pembelajaran kooperatif model Team Games Tournament (TGT) berbantuan media pembelajaran ular tangga redoks di kelas X 2 SMA Negeri 1 Tanjung," Quantum J. Inov. Pendidik. Sains, vol. 3, no. 2, 2012. 